EISSN: 2706 -7947 ISSN: 2077- 4613

DOI: $10.36632 /$ mejas/2021.11.3.51

Journal homepage: www.curresweb.com

Pages: 637-648

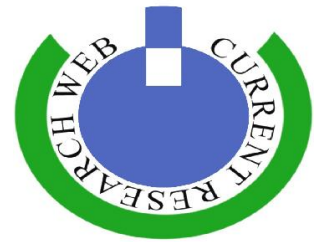

\title{
Improving Growth, Yield and Quality of Onion Plants by Amino and Humic Acids under Sandy Soil Conditions
}

\section{Hanaa A. Abd-Alrahman, Neama M. Marzouk, S.M. El-Sawy and S.D. Abou-Hussein}

Vegetable Research Dept., Agricultural \& Biological Research Division, National Research Centre (NRC), 33 El-Buhouth St., 12622 Dokki, Giza, Egypt.

Received: 22 June 2021 Accepted: 20 July $2021 \quad$ Published: 30 July 2021

\begin{abstract}
For improving the growth and increasing the production and chemical compositions of onion plants, two field experiments were established for studying the effect of amino acids and humic acid on onion plants grown in sandy soil. Three concentrations of mixed amino acids $(0,1$ and $2 \mathrm{~cm} / 1)$ as a foliar spraying and four rates of humic acid $(0,25,50$ and $75 \mathrm{~kg} /$ fed.) as a soil drench were applied. Results clearly indicated that increasing the concentration of amino acids significantly improved the vegetative growth characteristics and increased the production as well as enhanced the bulb chemical compositions compared to the control plants and the maximum values were noticed with $2 \mathrm{~cm} / 1$ amino acids treatment. Humic acid treatments had a positive effect on the onion plants, where $75 \mathrm{~kg} / \mathrm{fed}$. humic acid treatment produced the highest significant values of vegetative growth characteristics, yield and bulb physical properties and chemical compositions. It could be recommended that using amino acids at rate of $2 \mathrm{~cm} / 1$ as a foliar application mixed with humic acid at rate of 50 and $75 \mathrm{~kg} / \mathrm{fed}$. as a soil drench improve the growth and production as well as the chemical compositions for onion plants grown in sandy soil.
\end{abstract}

Keywords: Onion, amino acids and humic acid, production, quality and chemical composition

\section{Introduction}

Onion (Allium cepa L.) is the third important vegetable crops grown in Egypt comes after tomato and potato. It's cultivated for local consumption and exportation. The total cultivated area is about 195.47 thousands feddan, produced about 2.8 million ton with an average 16.50 tons/fed. (CAH, 2019). Onions are rich in carbohydrates, proteins, vitamin $\mathrm{A}$ and $\mathrm{C}$ beside minerals like $\mathrm{Ca}, \mathrm{P}$ and $\mathrm{Fe}$. (Jaggi, 2005). Especially, Egyptian onion is distinguished with high quality due to its high nutritional value and pungency, it can be eaten fresh, fried, roasted or boiled. It also used for, spice or medicinal purposes, as well as it plays an important role for reducing the blood sugar. With the limited water resources and increasing the population government should to think in the vertical expansion by increasing the production per area and improving the quality.

Amino acids are organic chemical compounds which considered the main components for protein synthesis in plants, which contributes in building vitamins, enzymes, other cell organs and plant tissues (Pratelli and Pilot, 2007; Liu et al., 2008 and El-Desouky et al., 2011). In agriculture, amino acids can be used for improving the plant growth, increasing the yield and reducing the injuries caused by abiotic stress, growers using foliar spraying of amino acids for supplying plants with their requirements. Using amino acids as a foliar application on plant shoot is one of the modern methods that used for enhancing the plant growth and productivity by overcoming the nutritional and environmental deficiencies which plants exposed to (Tugnoli and Bettini, 2003 and Shehata and Abdel-Wahab, 2018). In this concern, Calvo et al., (2014) suggested that plants which treated by amino acids had a tolerance to abiotic stresses and enhanced their growth and yield, this may be due to the role of amino acids in improving the efficiency of the plants' metabolism promoting the processes of plant respiration, photosynthesis, protein synthesis, which reflect on the plant growth and yield formation (Davies, 2010).

Corresponding Author: S.M. El-Sawy, Vegetable Research Dept., Agricultural \& Biological Research Division, National Research Centre (NRC), 33 El-Buhouth St., 12622 Dokki, Giza, Egypt.

E-mail: sameh_nrc@yahoo.com 
Decomposition process is chemical biological transformations for organic residuals with the help of microorganisms, produces humic substances such as humic acid, fulvic acid and humin (Canellas et al., 2008; Luciano et al., 2015 and Akthar et al., 2017). Humic substances enhance the soil physical and chemical properties and include stabilization of soil structure (Hartz and Bottoms, 2010) and increase cation exchange and nutrient uptake (Akinremi et al., 2000). Supplying the soil with humic substances increase the soil microflora and soil fertility which reflect on root and plant growth and plant nutrition as well as increase the plant tolerance for stress conditions (Chen and Aviad, 1990; Atiyeh et al., 2002; Pettit, 2004 and Olk et al., 2019).

Many investigators studied the effect of foliar application of mix of humic acid and amino acids, the results showed that potassium humate $\left(2 \mathrm{ml} \mathrm{L}^{-1}\right)$ and amino acids $(1000 \mathrm{ppm})$ produced the highest values of plant height, tuber diameter, total and marketable yield and nutrient balance of potato plants (Abd El-Rheem et al., 2020), as well as increased nutrient N, P and K content of potato tubers. While Shehata and Abdel-Wahab (2018) found that humic acid and amino acids treatments significantly increased the plant height, fruit weight and fruit diameter of sweet pepper. While, no significant differences were noticed among the treatments on fruit TSS of pepper fruits.

This study was established for investigating the effect of different concentrations of humic acid and/ or amino acids on vegetative growth, fruit yield and quality of onion plants grown in sandy soil.

\section{Materials and Methods}

Two field experiments were conducted during 2018/2019 and 2019/2020 growing seasons under newly reclaimed sandy soil conditions at the National Research Centre Experimental farm at ElNubaria, El-Behira Governorate, North of Egypt. Soil sample was taken and analyzed before planting and data is shown in Table (1).

This work aimed to study the effect of humic acid and amino acids on growth, yield and quality of onion plants grown in sandy soil drip irrigation system. Four rates of humic acid $(0,25,50$ and 75 $\mathrm{kg} / \mathrm{fed}$.) were added as soil drench. The mixed amino acids concentrations were applied as a foliar spraying at rates of 0,1 and $2 \mathrm{~cm} / 1$, three times per season (30,60 and 90 days after seedling date).

Onion seedlings cv. Giza 20 was transplanted at the second week of December in the two seasons. Seedlings were planted on drip irrigated laterals that were $1 \mathrm{~m}$ apart and $25 \mathrm{~m}$ long with $25 \mathrm{~cm}$ between drippers (standard $4 \mathrm{~L} / \mathrm{h}$ discharge at 1.5 bar drippers). Three irrigation lines were used as a border between treatments and were not included in the experiment to prevent the interaction between treatment plots. Four seedlings were planted around each dripper with $10 \mathrm{~cm}$ apart.

Table 1: Physical and chemical properties of the experimental soil.

\begin{tabular}{|c|c|c|c|c|c|c|c|}
\hline \multicolumn{8}{|c|}{ Physical properties } \\
\hline \multicolumn{2}{|c|}{ Sand } & Clay & Silt & Texture & Field capacity \% & \multicolumn{2}{|c|}{ Wilting point \% } \\
\hline \multicolumn{2}{|l|}{87.1} & 8.79 & 4.11 & Sandy & 17.18 & & \\
\hline \multicolumn{8}{|c|}{ Chemical analysis } \\
\hline \multirow{3}{*}{$\begin{array}{c}\text { E.C. } \\
\text { (dS m-1) } \\
2.75 \\
\end{array}$} & nH & \multicolumn{6}{|c|}{ Meq/L } \\
\hline & & $\mathbf{C a}$ & Mg & $\mathbf{N a}$ & $\mathbf{K}$ & $\mathrm{HCo}_{2}$ & Cl \\
\hline & 8.3 & 7.98 & 0.664 & 0.899 & 0.45 & 1.72 & 0.492 \\
\hline
\end{tabular}

\subsection{Experimental design}

The factorial experiment was consisting of 12 treatments with three replicates. The experiment was arranged in split plot design. Four levels of humic acid $(0,25,50$ and $75 \mathrm{~kg} / \mathrm{fed}$.) were occupied at the main plots and the three concentrations of mixed amino acids $(0,1,2 \mathrm{~cm} / \mathrm{l})$ were randomly allocated in the sub plots.

As for fertilization, $30 \mathrm{~m}^{3}$ organic manure per feddan plus 75 units /feddan of calcium superphosphate $\left(15 \% \mathrm{P}_{2} \mathrm{O}_{5}\right)$ at were added during the soil preparation. Nitrogen fertilizer was added in the form of ammonium sulphate ( $20.6 \mathrm{~N} / \mathrm{fed}$ ) at 150 units/ fed. (last $\mathrm{N}$ dose was 90 days after transplanting; about 60 days before lifting). Potassium sulphate $\left(48 \% \mathrm{~K}_{2} \mathrm{O}\right)$ was applied at a rate of 96 units per feddan at two times. The first dose (48 units) was added during preparation the soil for planting and the second dose (48 units) at the beginning of the formation of the bulbs. Cultural practices, disease and pest control management were followed according to the recommendations of the Egyptian Ministry of Agriculture. 


\subsection{Measurements of crop parameters \\ I. Vegetative growth}

A random sample of 5 onion plants were taken from each experimental plot at 120 days after transplanting

date and transferred to the laboratory to determine the following parameters:

- Plant length $(\mathrm{cm})$.

- Number of leaves per plant.

- Plant fresh weight (g/plant).

- Plant dry weight (g/plant).

\section{Bulb characteristics}

At harvesting time (when bulbs reach the variety normal bulb size and skin color which is about 150 days), onions were lifted by hand. Immediately after lifting, onions were subjected to field curing on the ground under shaded area for 10 days. After curing period bulbs were sorted and the following variables were measured:

- Average bulb weight (g)

- Dry matter percentage (D.M. \%): Bulb tissue was oven dried at $70^{\circ} \mathrm{C}$ for 72 hours and weighed then attributed to the initial fresh weight.

- Neck diameter $(\mathrm{cm})$.

- Bulb diameter (cm).

- Bulb length (cm).

\section{Yield and yield components}

After harvesting and bulb curing the following variables were also measured:

- Total yield $\left(\mathrm{kg} / \mathrm{m}^{2}\right)$.

- Marketable yield $\left(\mathrm{kg} / \mathrm{m}^{2}\right)$ : After removing the cull bulbs (includes bulbs of less than $3 \mathrm{~cm}$ diameter, doubles, bolters, off-colored and damaged bulbs), the remaining sound bulbs were considered as marketable yield.

\section{Bulb chemical quality parameters}

Another sample was taken to the lab in Vegetable Research Department, NRC, to measure bulb quality characteristics. Bulb quality was evaluated by measuring total soluble solids (TSS \%; determined by Hanna Digital Refractometer Model HI96801) and ascorbic acid (A.O.A.C., 1990), antioxidant activity (\%), total phenol content (mg/100g. D.W.) by Danial and George (1972) and crud protein $\%$ : a factor of 6.25 was used for conversion of total nitrogen to protein percentage. Total nitrogen content was estimated by modified Kjeldahl's methods, according to the described method of Cottenie et al., (1982).

\subsection{Statistical analysis}

All data were subjected to statistical analysis using MSTAT Computer Program (MSTAT Development Team, 1989). The Duncan's New Multiple Range test at 5\% level of probability was used to test the significance of differences among mean values of treatments (Steel and Torrie, 1980).

\section{Results and Discussion}

Data in Table (2) showed the effect of different concentrations of the mixed amino acids and humic acid on vegetative growth characteristics; plant length, number of leaves per plant, plant fresh weight and plant dry weight of onion plants. The results revealed that onion plants which received amino acids at $2 \mathrm{~cm} / 1$ produced the highest significant values of plant length, number of leaves per plant, plant fresh weight and plant dry weight. The previous vegetative characteristics of onion plants were significantly higher with the highest application rate of humic acid at $75 \mathrm{~kg} / \mathrm{fed}$. in the two studied seasons, while the lowest values were noticed with control treatments. For the interaction between amino acids and humic acid treatments, data showed that the foliar spraying of amino acids at $2 \mathrm{~cm} / 1$ and soil drench of humic acid (50 and $75 \mathrm{~kg} / \mathrm{fed}$.) achieved the highest vegetative growth for onion plants compared to the other studied treatments with significant differences among them. These results 
Table 2: Effect of amino acids and humic acid on vegetative growth parameters of onion plants in 2018/2019 and 2019/2020 seasons.

\begin{tabular}{|c|c|c|c|c|c|c|c|c|c|}
\hline \multicolumn{6}{|c|}{ First season } & \multicolumn{4}{|c|}{ Second season } \\
\hline \multicolumn{2}{|c|}{ Treatments } & $\begin{array}{c}\text { Plant } \\
\text { height } \\
\text { (cm.) }\end{array}$ & $\begin{array}{c}\text { No. of } \\
\text { leaves/plant }\end{array}$ & $\begin{array}{c}\text { F.W. } \\
\text { g./plant }\end{array}$ & $\begin{array}{l}\text { D.W. } \\
\text { g./plant }\end{array}$ & $\begin{array}{c}\text { Plant } \\
\text { height } \\
\text { (cm.) }\end{array}$ & $\begin{array}{c}\text { No. of } \\
\text { leaves/plant }\end{array}$ & $\begin{array}{c}\text { F.W. } \\
\text { g./plant }\end{array}$ & $\begin{array}{c}\text { D.W. } \\
\text { g./plant }\end{array}$ \\
\hline \multicolumn{10}{|c|}{ Amino levels $(\mathrm{cm} / \mathrm{L})$} \\
\hline \multicolumn{2}{|c|}{$\mathbf{0}$} & $99.60 \mathrm{C}$ & $5.90 \mathrm{C}$ & $403.40 \mathrm{C}$ & $34.90 \mathrm{C}$ & $91.20 \mathrm{C}$ & $6.10 \mathrm{C}$ & $393.00 \mathrm{C}$ & $30.70 \mathrm{C}$ \\
\hline \multicolumn{2}{|c|}{1} & $103.00 \mathrm{~B}$ & $6.37 \mathrm{~B}$ & $414.20 \mathrm{~B}$ & $38.10 \mathrm{~B}$ & $94.40 \mathrm{~B}$ & $6.50 \mathrm{~B}$ & $403.80 \mathrm{~B}$ & $33.30 \mathrm{~B}$ \\
\hline \multicolumn{2}{|c|}{2} & $105.80 \mathrm{~A}$ & $7.10 \mathrm{~A}$ & $424.60 \mathrm{~A}$ & $41.60 \mathrm{~A}$ & $98.50 \mathrm{~A}$ & $7.00 \mathrm{~A}$ & $411.40 \mathrm{~A}$ & $36.50 \mathrm{~A}$ \\
\hline \multicolumn{10}{|c|}{ Humic acid (kg/fed.) } \\
\hline \multicolumn{2}{|c|}{$\mathbf{0}$} & $103.20 \mathrm{D}$ & $6.80 \mathrm{D}$ & $415.30 \mathrm{D}$ & $39.50 \mathrm{D}$ & $96.00 \mathrm{D}$ & $6.70 \mathrm{D}$ & $401.50 \mathrm{D}$ & $34.90 \mathrm{D}$ \\
\hline \multicolumn{2}{|c|}{25} & $104.70 \mathrm{C}$ & $7.10 \mathrm{C}$ & $421.70 \mathrm{C}$ & $41.10 \mathrm{C}$ & $97.40 \mathrm{C}$ & $7.00 \mathrm{C}$ & $408.10 \mathrm{C}$ & $36.50 \mathrm{C}$ \\
\hline \multicolumn{2}{|c|}{50} & $106.00 \mathrm{~B}$ & $7.50 \mathrm{~B}$ & $425.60 \mathrm{~B}$ & $42.20 \mathrm{~B}$ & $100.10 \mathrm{~B}$ & $7.20 \mathrm{~B}$ & $412.80 \mathrm{~B}$ & $37.70 \mathrm{~B}$ \\
\hline \multicolumn{2}{|c|}{75} & $108.50 \mathrm{~A}$ & $8.00 \mathrm{~A}$ & $428.00 \mathrm{~A}$ & $44.60 \mathrm{~A}$ & $101.60 \mathrm{~A}$ & $7.30 \mathrm{~A}$ & $416.70 \mathrm{~A}$ & $39.10 \mathrm{~A}$ \\
\hline \multicolumn{10}{|c|}{ The interaction } \\
\hline \multirow{4}{*}{$\mathbf{0}$} & $\mathbf{0}$ & $96.50 \mathrm{i}$ & $5.40 \mathrm{i}$ & $390.30 \mathrm{i}$ & $32.10 \mathrm{i}$ & $89.20 \mathrm{~h}$ & $5.90 \mathrm{i}$ & $380.90 \mathrm{i}$ & $29.30 \mathrm{i}$ \\
\hline & 25 & $99.50 \mathrm{i}$ & $5.80 \mathrm{~h}$ & $405.30 \mathrm{~h}$ & $34.50 \mathrm{~h}$ & $90.10 \mathrm{~h}$ & $6.10 \mathrm{~h}$ & $390.60 \mathrm{i}$ & $30.10 \mathrm{i}$ \\
\hline & 50 & $100.30 \mathrm{~h}$ & $6.10 \mathrm{~g}$ & $407.10 \mathrm{~g}$ & $35.50 \mathrm{gh}$ & $92.10 \mathrm{~g}$ & $6.30 \mathrm{~g}$ & $399.50 \mathrm{~h}$ & $31.20 \mathrm{~h}$ \\
\hline & 75 & $102.30 \mathrm{~g}$ & $6.30 \mathrm{f}$ & $411.20 \mathrm{f}$ & $37.50 \mathrm{~g}$ & $93.40 \mathrm{~g}$ & $6.40 \mathrm{f}$ & $401.20 \mathrm{~g}$ & $32.40 \mathrm{~g}$ \\
\hline \multirow{4}{*}{1} & $\mathbf{0}$ & $104.60 \mathrm{f}$ & $6.40 \mathrm{ef}$ & $418.40 \mathrm{e}$ & $39.60 \mathrm{f}$ & $95.40 \mathrm{f}$ & $6.70 \mathrm{ef}$ & $403.30 \mathrm{fg}$ & $34.30 \mathrm{f}$ \\
\hline & 25 & $105.10 \mathrm{e}$ & $6.70 \mathrm{e}$ & $420.20 \mathrm{de}$ & $40.10 \mathrm{e}$ & $96.70 \mathrm{ef}$ & $6.90 \mathrm{e}$ & $411.20 \mathrm{f}$ & $35.40 \mathrm{e}$ \\
\hline & $\mathbf{5 0}$ & $106.30 \mathrm{f}$ & $7.20 \mathrm{~d}$ & $429.70 \mathrm{~d}$ & $41.20 \mathrm{de}$ & $100.70 \mathrm{e}$ & $7.10 \mathrm{~d}$ & $412.40 \mathrm{e}$ & $36.70 \mathrm{~d}$ \\
\hline & 75 & $107.40 \mathrm{~d}$ & $8.10 \mathrm{~cd}$ & $430.30 \mathrm{c}$ & $45.60 \mathrm{~d}$ & $101.20 \mathrm{~d}$ & $7.30 \mathrm{~cd}$ & $418.80 \mathrm{~d}$ & $39.60 \mathrm{~cd}$ \\
\hline \multirow{4}{*}{2} & 0 & $108.40 \mathrm{c}$ & $8.50 \mathrm{c}$ & $437.10 \mathrm{bc}$ & $46.70 \mathrm{c}$ & $103.40 \mathrm{c}$ & $7.60 \mathrm{c}$ & $420.30 \mathrm{~cd}$ & $41.20 \mathrm{c}$ \\
\hline & 25 & $109.50 \mathrm{~b}$ & $8.90 \mathrm{~b}$ & $439.70 \mathrm{~b}$ & $48.70 \mathrm{~b}$ & $105.30 \mathrm{~b}$ & $7.90 \mathrm{~b}$ & $422.50 \mathrm{~b}$ & $42.40 \mathrm{~b}$ \\
\hline & 50 & $111.40 \mathrm{ab}$ & $9.10 \mathrm{ab}$ & $440.10 \mathrm{ab}$ & $49.80 \mathrm{ab}$ & $107.40 \mathrm{ab}$ & $8.10 \mathrm{ab}$ & $426.40 \mathrm{ab}$ & $44.30 \mathrm{ab}$ \\
\hline & 75 & $115.70 \mathrm{a}$ & $9.50 \mathrm{a}$ & $442.50 \mathrm{a}$ & $50.70 \mathrm{a}$ & $110.30 \mathrm{a}$ & $8.30 \mathrm{a}$ & $430.20 \mathrm{a}$ & $45.30 \mathrm{a}$ \\
\hline
\end{tabular}

Values followed by the same letter (s) within column are not significantly different $(\mathrm{P}<0.05)$ 
are in harmony with these obtained by El-Zohiri and Asfour (2009) on potatoes, Abdel-Mawgoud et al., (2011) on green bean and Korkmaz et al., (2012) on sweet pepper. This may be due to the role of amino acids for stimulating of cell growth. Amino acids are considered as precursors and constituent and acts as buffers which help to maintain favorable $\mathrm{pH}$ value within the plant cell (Rai 2002). Humic acids stimulate root growth, increase proliferation of root hairs, production of smaller but more ramified secondary roots and enhancement of root initiation (Canellas et al., 2014). The positive effect of humic on plant growth and productivity, which seems to be mainly due to hormone-like activities of the humic acids through their involvement in cell respiration, photosynthesis, oxidative phosphorylation, protein synthesis and various enzymatic reactions. In this concern, the authors suggested that there were remarkable effects for humic acid on vegetative growth, yield and nutritional statues of potato plants (Radwan and El- Shall, 2011 and Sarhan, 2011). In addition, Rizk et al., (2013) concluded that potato plants which received humic acid at $30 \mathrm{~cm} / 1$ produced the highest vegetative growth. Moreover, ElBassiony et al., (2020) found that onion plants which received amino acids as a foliar application produced the highest significant values of plant length, number of leaves, fresh weight of leaves and bulbs and dry weight of leaves. Furthermore, Shaheen et al., (2013) found that vegetative growth characteristics; plant length, leaves number, fresh and dry weights of leaves and bulbs were enhanced with amino acids treatments $(2$ and $3 \mathrm{~cm} / \mathrm{L}$ ). Many investigators confirmed that plants which treated by amino acids mixture as a foliar spraying had a significant increment in vegetative growth parameters and number of flowers of potatoes (El-Zohiri and Asfour, 2009) and green bean (Abdel-Mawgoud et al., 2011).

Data presented in Table (3) showed the effect of different concentrations of the mixed amino acids and humic acid on yield parameters i.e., neck diameter, bulb diameter, bulb length, and bulb fresh and dry weights of onions. Results showed that amino acids treatments had a positive effect on bulb diameter, and bulb length and bulb fresh and dry weight of onions. Whereas the highest significant values for bulb diameter, bulb length and bulb fresh and dry weight were noticed with treatment of amino acids at rate of $2 \mathrm{~cm} / 1$ and the minimum values were found with control treatment $(0 \mathrm{~cm} / 1)$ in the both tested seasons. On the contrary, neck diameter decreased with amino acids treatments where the highest significant values were noticed with control plants and the lowest values were found with treatment of amino acids at $2 \mathrm{~cm} / \mathrm{l}$. The effect of humic acid on the physical properties of the onion bulbs was clear, where data in Table (3) illustrated that onion plants which treated by humic acid as a soil drench at $75 \mathrm{~kg} / \mathrm{fed}$. achieved the maximum significant values of bulb diameter, bulb length and bulb fresh and dry weights during the two growing seasons. While humic acid treatments significantly decreased the neck diameter and the highest significant values were achieved with control treatment. The combined effect of amino acids and humic acid treatments showed that onion plants which received the treatments of amino acids at $2 \mathrm{~cm} / 1$ as a foliar application and humic acid at rates of 50 and 75 $\mathrm{kg} / \mathrm{fed}$. as a soil drench produced the highest significant values of bulb diameter, bulb length and bulb fresh and dry weights. On the contrary, neck diameter significantly decreased with the interaction of studied treatments amino acids ( 1 and $2 \mathrm{~cm} / \mathrm{l})$ with humic acid $(25,50$ and $75 \mathrm{~kg} / \mathrm{fed}$.) and the highest significant values were noticed with control plants. This may be due to amino acids are considered the fundamental materials in the process of protein synthesis which help plants to create tissues and organs (El-Desouky et al., 2011). Also our results agree with these obtained by Sajid at al. (2012) who mentioned that humic acids treatments increased neck height, bulb weight, and total yield ha ${ }^{-1}$ and this may be due to humic acid increased the fertilizer efficiency and improved the soil fertility, as well as humic acid enhanced the root growth which reflect on the vegetative growth, bulb size and onion production (Kandil et al., 2013 and Doklega, 2017). In the same trend, El-Bassiony et al., (2020) and Shaheen et al., (2013) suggested that onion plants which treated by amino acids $(2$ and $3 \mathrm{~cm} / \mathrm{L})$ as a foliar spraying produced the maximum significant values of bulb fresh and dry weights, bulb diameter. On potato plants, humic acid treatments improved the vegetative growth and yield characteristics (Radwan and El- Shall, 2011, Sarhan, 2011 and Rizk et al., 2013). 
Table 3: Effect of amino acids and humic acid on physical parameters of onions in 2018/2019 and 2019/2020 seasons.

\begin{tabular}{|c|c|c|c|c|c|c|c|c|c|c|c|}
\hline \multicolumn{7}{|c|}{ First season } & \multicolumn{5}{|c|}{ Second season } \\
\hline & nts & $\begin{array}{c}\text { Neck } \\
\text { diameter } \\
(\mathbf{c m} .) \\
\end{array}$ & $\begin{array}{c}\text { Bulb } \\
\text { diameter } \\
(\mathbf{c m} .) \\
\end{array}$ & $\begin{array}{c}\text { Bulb } \\
\text { length } \\
\text { (cm.) } \\
\end{array}$ & $\begin{array}{l}\text { Bulb fresh } \\
\text { weight (g.) }\end{array}$ & $\begin{array}{c}\text { Bulb dry } \\
\text { weight (g.) }\end{array}$ & $\begin{array}{c}\text { Neck } \\
\text { diameter } \\
(\mathbf{c m} .) \\
\end{array}$ & $\begin{array}{c}\text { Bulb } \\
\text { diameter } \\
(\mathbf{c m} .) \\
\end{array}$ & $\begin{array}{c}\text { Bulb } \\
\text { length } \\
\text { (cm.) } \\
\end{array}$ & $\begin{array}{l}\text { Bulb fresh } \\
\text { weight (g.) }\end{array}$ & $\begin{array}{c}\text { Bulb dry } \\
\text { weight (g.) }\end{array}$ \\
\hline \multicolumn{12}{|c|}{ Amino levels $(\mathrm{cm} / \mathrm{L})$} \\
\hline & & $1.22 \mathrm{~A}$ & $4.80 \mathrm{C}$ & $4.48 \mathrm{C}$ & $87.20 \mathrm{C}$ & $8.20 \mathrm{C}$ & $1.14 \mathrm{~A}$ & $5.80 \mathrm{~A}$ & $4.68 \mathrm{C}$ & $85.35 \mathrm{C}$ & $8.00 \mathrm{C}$ \\
\hline & & $1.19 \mathrm{~B}$ & $5.00 \mathrm{~B}$ & $4.89 \mathrm{~B}$ & $91.10 \mathrm{~B}$ & $8.70 \mathrm{~B}$ & $1.18 \mathrm{~B}$ & $5.40 \mathrm{~B}$ & $4.89 \mathrm{~B}$ & $87.20 \mathrm{~B}$ & $8.50 \mathrm{~B}$ \\
\hline & & $1.15 \mathrm{C}$ & $5.40 \mathrm{~A}$ & $5.44 \mathrm{~A}$ & $94.40 \mathrm{~A}$ & $9.20 \mathrm{~A}$ & $1.24 \mathrm{~A}$ & $4.90 \mathrm{C}$ & $5.06 \mathrm{~A}$ & $89.42 \mathrm{~A}$ & $9.00 \mathrm{~A}$ \\
\hline \multicolumn{12}{|c|}{ Humic acid (kg/fed.) } \\
\hline & & $1.25 \mathrm{~A}$ & $4.50 \mathrm{D}$ & $5.00 \mathrm{D}$ & $91.60 \mathrm{D}$ & $8.80 \mathrm{D}$ & $1.20 \mathrm{D}$ & $5.20 \mathrm{~A}$ & $4.88 \mathrm{C}$ & $90.50 \mathrm{D}$ & $8.90 \mathrm{D}$ \\
\hline & & $1.23 \mathrm{~B}$ & $4.70 \mathrm{C}$ & $5.20 \mathrm{C}$ & $93.30 \mathrm{C}$ & $9.20 \mathrm{C}$ & $1.23 \mathrm{C}$ & $5.00 \mathrm{~B}$ & $5.07 \mathrm{BC}$ & $91.60 \mathrm{C}$ & $9.10 \mathrm{C}$ \\
\hline & & $1.21 \mathrm{C}$ & $4.90 \mathrm{~B}$ & $5.50 \mathrm{~B}$ & $96.10 \mathrm{~B}$ & $9.30 \mathrm{~B}$ & $1.26 \mathrm{~B}$ & $4.80 \mathrm{C}$ & $5.22 \mathrm{~B}$ & $92.00 \mathrm{~B}$ & $9.40 \mathrm{~B}$ \\
\hline & & $1.96 \mathrm{D}$ & $5.00 \mathrm{~A}$ & $5.70 \mathrm{~A}$ & $97.60 \mathrm{~A}$ & $9.70 \mathrm{~A}$ & $1.29 \mathrm{~A}$ & $4.50 \mathrm{D}$ & $5.38 \mathrm{~A}$ & $92.70 \mathrm{~A}$ & $9.90 \mathrm{~A}$ \\
\hline \multicolumn{12}{|c|}{ The interaction } \\
\hline \multirow{4}{*}{$\mathbf{0}$} & $\mathbf{0}$ & $1.31 \mathrm{a}$ & $3.90 \mathrm{i}$ & $4.12 \mathrm{i}$ & $84.20 \mathrm{~g}$ & $7.90 \mathrm{~g}$ & $1.11 \mathrm{~g}$ & $6.10 \mathrm{a}$ & $4.60 \mathrm{~h}$ & $84.20 \mathrm{~h}$ & $7.60 \mathrm{~h}$ \\
\hline & 25 & $1.29 \mathrm{ab}$ & $4.10 \mathrm{~h}$ & $4.35 \mathrm{~h}$ & $85.20 \mathrm{fg}$ & $8.10 \mathrm{f}$ & $1.14 \mathrm{f}$ & $5.90 \mathrm{ab}$ & $4.56 \mathrm{~g}$ & $85.30 \mathrm{~g}$ & $7.90 \mathrm{~g}$ \\
\hline & 50 & $1.28 \mathrm{~b}$ & $4.30 \mathrm{~h}$ & $4.67 \mathrm{~g}$ & $89.50 \mathrm{f}$ & $8.30 \mathrm{f}$ & $1.15 \mathrm{f}$ & $5.70 \mathrm{~b}$ & $4.67 \mathrm{~g}$ & $85.40 \mathrm{~g}$ & $8.10 \mathrm{~g}$ \\
\hline & 75 & $1.27 \mathrm{c}$ & $4.40 \mathrm{gh}$ & $4.78 \mathrm{fg}$ & $90.10 \mathrm{e}$ & $8.60 \mathrm{e}$ & $1.17 \mathrm{e}$ & $5.50 \mathrm{bc}$ & $4.89 \mathrm{f}$ & $86.50 \mathrm{f}$ & $8.40 \mathrm{f}$ \\
\hline \multirow{4}{*}{1} & $\mathbf{0}$ & $1.25 \mathrm{~cd}$ & $4.60 \mathrm{~g}$ & $4.90 \mathrm{f}$ & $91.30 \mathrm{e}$ & $8.90 \mathrm{e}$ & $1.18 \mathrm{e}$ & $5.30 \mathrm{c}$ & $4.90 \mathrm{e}$ & $87.70 \mathrm{e}$ & $8.60 \mathrm{e}$ \\
\hline & 25 & $1.23 \mathrm{~d}$ & $4.70 \mathrm{f}$ & $5.23 \mathrm{e}$ & 93.50de & $9.10 \mathrm{de}$ & $1.23 \mathrm{de}$ & $5.10 \mathrm{~cd}$ & $5.10 \mathrm{de}$ & $89.20 \mathrm{de}$ & $8.90 \mathrm{de}$ \\
\hline & 50 & $1.21 \mathrm{de}$ & $4.90 \mathrm{ef}$ & $5.67 \mathrm{~d}$ & $95.60 \mathrm{~d}$ & $9.30 \mathrm{~d}$ & $1.27 \mathrm{~d}$ & $4.90 \mathrm{~d}$ & $5.11 \mathrm{~d}$ & $90.10 \mathrm{~d}$ & $9.10 \mathrm{~d}$ \\
\hline & 75 & $1.20 \mathrm{e}$ & $5.00 \mathrm{e}$ & $5.97 \mathrm{~cd}$ & $97.50 \mathrm{~cd}$ & $9.50 \mathrm{~cd}$ & $1.29 \mathrm{~cd}$ & $4.50 \mathrm{e}$ & $5.13 \mathrm{c}$ & $90.70 \mathrm{c}$ & $9.60 \mathrm{c}$ \\
\hline \multirow{4}{*}{2} & $\mathbf{0}$ & $1.19 \mathrm{f}$ & $5.10 \mathrm{~d}$ & $5.99 \mathrm{c}$ & $99.50 \mathrm{c}$ & $9.70 \mathrm{c}$ & $1.31 \mathrm{c}$ & $4.30 \mathrm{f}$ & $5.15 \mathrm{bc}$ & $99.80 \mathrm{bc}$ & $10.40 \mathrm{bc}$ \\
\hline & 25 & $1.17 \mathrm{fg}$ & $5.30 \mathrm{c}$ & $6.20 \mathrm{~b}$ & $101.20 \mathrm{~b}$ & $10.40 \mathrm{~b}$ & $1.34 \mathrm{~b}$ & $4.10 \mathrm{~g}$ & $5.56 \mathrm{~b}$ & $100.30 \mathrm{~b}$ & $10.70 \mathrm{~b}$ \\
\hline & 50 & $1.14 \mathrm{~h}$ & $5.70 \mathrm{~b}$ & $6.33 \mathrm{ab}$ & $103.20 \mathrm{ab}$ & $10.50 \mathrm{ab}$ & $1.36 \mathrm{ab}$ & $3.90 \mathrm{~h}$ & $5.89 \mathrm{ab}$ & $100.70 \mathrm{ab}$ & $11.10 \mathrm{ab}$ \\
\hline & 75 & $1.12 \mathrm{~h}$ & $5.80 \mathrm{a}$ & $6.42 \mathrm{a}$ & $105.30 \mathrm{a}$ & $11.10 \mathrm{a}$ & $1.41 \mathrm{a}$ & $3.70 \mathrm{i}$ & $6.12 \mathrm{a}$ & $100.90 \mathrm{a}$ & $11.70 \mathrm{a}$ \\
\hline
\end{tabular}

Values followed by the same letter (s) within column are not significantly different $(\mathrm{P}<0.05)$ 
Data in Table (4) showed the effect of different concentrations of the mixed amino acids and humic acid on total yield, marketable yield, dry matter and T.S.S of onions plants. The results indicated that onion plants which received amino acids at $2 \mathrm{~cm} / 1$ produced the highest significant values of total yield, marketable yield, dry matter and T.S.S of onions. While, the effect of humic acid treatments on onion yield characteristics, data showed that application of humic acid at $75 \mathrm{~kg} / \mathrm{fed}$. significantly increased the yield mentioned characteristics compared to the other concentrations in the two growing seasons, whereas the lowest values were noticed with control treatment. As for the interaction between amino acids and humic acid treatments, data showed that the foliar spraying of amino acids at $2 \mathrm{~cm} / 1$ with soil drench of humic acid at 50 and $75 \mathrm{~kg} / \mathrm{fed}$. achieved the highest values of total yield, marketable yield, dry matter and T.S.S of onions compared to the other studied treatments with significant differences among them. These results are in harmony with these obtained by El-Zohiri and Asfour (2009), Abdel-Mawgoud et al., (2011) on green bean and Korkmaz et al., (2012) on sweet pepper. In addition, Shaheen et al., (2013) and El-Bassiony et al., (2020) found that total yield per feddan, TSS, leaves and bulbs $\mathrm{N}$ and $\mathrm{K} \%$ were recorded the maximum values with amino acids treatments at levels within 2 and $3 \mathrm{~cm} / \mathrm{L}$. Furthermore, the foliar application of humic acid on onion plants increased the vegetative growth and total and marketable yields, bulb weight and chemical composition, as well as improved the TSS \%, dry matter and total weight loss percentages at storage period of onions (Geries, 2013). This is may be due to humic substances recognized as a plant growth promoter which result in increasing root hair and size with larger surface area (Canellas and Olivares 2014). In the same trend, Marschener (2012) found that humic acid treatments improved soil $\mathrm{pH}$ which reflected on mineral elements availability for plant roots and consequently improved plant growth and productivity.in addition, many investigators confirmed the positive effect of humic acid on fruit yield and quality of cowpea plant (Abdelhamid et al., 2011), hot pepper (Serna et al., 2012 and Shafeek et al., 2014) and sweet pepper (Shehata and Abdel-Wahab, 2018).

Data presented in Table (5) the response of different concentrations of the mixed amino acids and humic acid on chemical composition characteristics ascorbic i.e., ascorbic acid, antioxidant activity, crud protein and total phenol content of onions. Results showed that amino acids treatments had a positive effect on ascorbic acid, antioxidant activity, crud protein and total phenol content parameters. Whereas the highest significant values were noticed with treatment of amino acids at $2 \mathrm{~cm} / 1$ and the minimum values were found with control treatment $(0 \mathrm{~cm} / 1)$ in the both tested seasons. The effect of humic acid on the bulb chemical compositions was clear, where data in Table (5) revealed that onion plants which treated by humic acid as a soil drench at $75 \mathrm{~kg} / \mathrm{fed}$. achieved the maximum significant values of ascorbic acid, antioxidant activity, crud protein and total phenol content during the two growing seasons. Regarding the effect of the interaction between amino acids and humic acid treatments, data showed that onion plants which treated by amino acids at rate of $2 \mathrm{~cm} / 1$ (as a foliar application) and humic acid at rated of $50,75 \mathrm{~kg} / \mathrm{fed}$. (as a soil drench) produced the highest significant values of the above mentioned characteristics. In the same trend, Zhang (1997) suggested that foliar application of humic acid consistently enhanced antioxidants such as a-tocopheral, B-carotene, superoxide dismutases and ascorbic acid concentration. These antioxidants may play a role in the regulation of plant. Also Bama and Selvakumari (2001) found that application of $10 \mathrm{~kg}$ humic acid ha${ }^{1}$ as potassium humate increased crude protein content and mineral nutrition $(\mathrm{P}, \mathrm{K}, \mathrm{Ca}, \mathrm{Mg}, \mathrm{Zn}, \mathrm{Cu}, \mathrm{Fe}$ and $\mathrm{Mn}$ ) of amaranths. Furthermore, Abd El-Rheem et al., (2020) found that potassium humate ( $2 \mathrm{ml}$ $\left.\mathrm{L}^{-1}\right)$ and amino acids $(1000 \mathrm{ppm})$ produced the highest values of tuber quality parameters and increased the nutrient in potatoes. Moreover, El-Bassiony et al., (2020) reported that onion plants which sprayed by amino acids had the highest significant values of leaves and bulbs $\mathrm{N}$ and $\mathrm{K} \%$. While there were no significant differences among the treatments for $\mathrm{P} \%$, the same results were achieved with potato plants (Rizk et al., 2013).

\section{Conclusions}

According the results of this study, it could be concluded that for improving the vegetative growth, maximizing the production and enhancing the quality and chemical compositions of onions, the mixed amino acids should be used at rate of $2 \mathrm{~cm} / 1$ as a foliar application (three times per season; 30,60 and 90 days after seedling date) and humic acid at rate of 50 or $75 \mathrm{~kg} / \mathrm{fed}$. as a soil drench. 
Table 4: Effect of amino acids and humic acid on yield parameters of onions in 2018/2019 and 2019/2020 seasons

\begin{tabular}{|c|c|c|c|c|c|c|c|c|c|}
\hline \multicolumn{6}{|c|}{ First season } & \multicolumn{4}{|c|}{ Second season } \\
\hline \multicolumn{2}{|c|}{ Treatments } & $\begin{array}{c}\text { Total yield } \\
\text { (ton/fed.) }\end{array}$ & $\begin{array}{c}\text { Marketable yield } \\
\text { (ton/fed.) }\end{array}$ & $\begin{array}{c}\text { Dry matter } \\
(\%)\end{array}$ & T.S.S. & $\begin{array}{c}\text { Total yield } \\
\text { (ton/fed.) }\end{array}$ & $\begin{array}{c}\text { Marketable yield } \\
\text { (ton/fed.) }\end{array}$ & $\begin{array}{c}\text { Dry matter } \\
(\%)\end{array}$ & T.S.S. \\
\hline \multicolumn{10}{|c|}{ Amino levels $(\mathrm{cm} / \mathrm{L})$} \\
\hline \multicolumn{2}{|c|}{$\mathbf{0}$} & $10.75 \mathrm{C}$ & $8.01 \mathrm{C}$ & $14.17 \mathrm{C}$ & $10.46 \mathrm{C}$ & $9.56 \mathrm{C}$ & $7.03 \mathrm{C}$ & $14.56 \mathrm{C}$ & $10.35 \mathrm{C}$ \\
\hline \multicolumn{2}{|c|}{1} & $11.25 \mathrm{~B}$ & $8.45 \mathrm{~B}$ & $14.94 \mathrm{~B}$ & $10.98 \mathrm{~B}$ & $10.06 \mathrm{~B}$ & $7.55 \mathrm{~B}$ & 14.87 B & $11.14 \mathrm{~B}$ \\
\hline \multicolumn{2}{|c|}{2} & $11.89 \mathrm{~A}$ & $8.89 \mathrm{~A}$ & $15.35 \mathrm{~A}$ & $11.59 \mathrm{~A}$ & $10.67 \mathrm{~A}$ & $8.03 \mathrm{~A}$ & $15.22 \mathrm{~A}$ & $11.81 \mathrm{~A}$ \\
\hline \multicolumn{10}{|c|}{ Humic acid (kg/fed.) } \\
\hline \multicolumn{2}{|c|}{$\mathbf{0}$} & $11.48 \mathrm{D}$ & $8.59 \mathrm{D}$ & $14.97 \mathrm{D}$ & $11.23 \mathrm{D}$ & $10.26 \mathrm{D}$ & $7.74 \mathrm{D}$ & $15.23 \mathrm{D}$ & $11.22 \mathrm{D}$ \\
\hline \multicolumn{2}{|c|}{25} & $11.89 \mathrm{C}$ & $8.75 \mathrm{C}$ & $15.30 \mathrm{C}$ & $11.41 \mathrm{C}$ & $10.53 \mathrm{C}$ & $7.90 \mathrm{C}$ & $15.52 \mathrm{C}$ & $11.52 \mathrm{C}$ \\
\hline \multicolumn{2}{|c|}{50} & $11.97 \mathrm{~B}$ & $9.10 \mathrm{~B}$ & $15.74 \mathrm{~B}$ & $11.59 \mathrm{~B}$ & $10.70 \mathrm{~B}$ & $8.11 \mathrm{~B}$ & $15.69 \mathrm{~B}$ & $11.77 \mathrm{~B}$ \\
\hline \multicolumn{2}{|c|}{75} & $12.23 \mathrm{~A}$ & $9.43 \mathrm{~A}$ & $16.22 \mathrm{~A}$ & $11.82 \mathrm{~A}$ & $11.17 \mathrm{~A}$ & $8.26 \mathrm{~A}$ & $16.00 \mathrm{~A}$ & $12.20 \mathrm{~A}$ \\
\hline \multicolumn{10}{|c|}{ The interaction } \\
\hline \multirow{4}{*}{$\mathbf{0}$} & $\mathbf{0}$ & $10.45 \mathrm{~h}$ & $7.56 \mathrm{i}$ & $13.12 \mathrm{i}$ & $10.23 \mathrm{~h}$ & $9.23 \mathrm{~h}$ & $6.78 \mathrm{i}$ & $14.23 \mathrm{i}$ & $9.88 \mathrm{i}$ \\
\hline & 25 & $10.56 \mathrm{~h}$ & $7.90 \mathrm{~h}$ & $14.12 \mathrm{~h}$ & $10.41 \mathrm{gh}$ & $9.45 \mathrm{gh}$ & $6.90 \mathrm{gh}$ & $14.56 \mathrm{gh}$ & $10.12 \mathrm{~h}$ \\
\hline & 50 & $10.90 \mathrm{~h}$ & $8.10 \mathrm{~g}$ & $14.56 \mathrm{gh}$ & $10.56 \mathrm{~g}$ & $9.67 \mathrm{~g}$ & $7.10 \mathrm{~g}$ & $14.67 \mathrm{~g}$ & $10.45 \mathrm{~g}$ \\
\hline & 75 & $11.12 \mathrm{~g}$ & $8.50 \mathrm{f}$ & $14.89 \mathrm{~g}$ & $10.67 \mathrm{fg}$ & $9.89 \mathrm{fg}$ & $7.34 \mathrm{fg}$ & $14.78 \mathrm{fg}$ & $10.89 \mathrm{f}$ \\
\hline \multirow{4}{*}{1} & 0 & $11.45 \mathrm{f}$ & 8.67 ef & $15.45 \mathrm{f}$ & $11.23 \mathrm{f}$ & $10.12 \mathrm{f}$ & $7.89 \mathrm{f}$ & $14.79 \mathrm{f}$ & $11.45 \mathrm{e}$ \\
\hline & 25 & $11.56 \mathrm{f}$ & $8.56 \mathrm{e}$ & $14.89 \mathrm{e}$ & $11.49 \mathrm{e}$ & $10.56 \mathrm{e}$ & $7.90 \mathrm{e}$ & $15.11 \mathrm{e}$ & $11.78 \mathrm{de}$ \\
\hline & 50 & $12.12 \mathrm{e}$ & $9.10 \mathrm{~d}$ & $15.11 \mathrm{~d}$ & $11.78 \mathrm{~d}$ & $10.78 \mathrm{~d}$ & $8.12 \mathrm{~d}$ & $15.23 \mathrm{~d}$ & $11.90 \mathrm{~d}$ \\
\hline & 75 & $12.45 \mathrm{de}$ & $9.23 \mathrm{~cd}$ & $15.89 \mathrm{~cd}$ & $11.89 \mathrm{~cd}$ & $11.23 \mathrm{~cd}$ & $8.23 \mathrm{~cd}$ & $15.78 \mathrm{~cd}$ & $12.11 \mathrm{~cd}$ \\
\hline \multirow{4}{*}{2} & 0 & $12.56 \mathrm{~d}$ & $9.56 \mathrm{c}$ & $16.34 \mathrm{c}$ & $12.23 \mathrm{c}$ & $11.45 \mathrm{c}$ & $8.56 \mathrm{c}$ & $16.67 \mathrm{c}$ & $12.34 \mathrm{c}$ \\
\hline & 25 & $12.78 \mathrm{c}$ & $9.79 \mathrm{~b}$ & $16.90 \mathrm{~b}$ & $12.35 \mathrm{~b}$ & $11.56 \mathrm{~b}$ & $8.90 \mathrm{~b}$ & $16.90 \mathrm{~b}$ & $12.67 \mathrm{~b}$ \\
\hline & 50 & $12.90 \mathrm{~b}$ & $10.12 \mathrm{ab}$ & $17.56 \mathrm{ab}$ & $12.45 \mathrm{ab}$ & $11.67 \mathrm{ab}$ & $9.12 \mathrm{ab}$ & $17.17 \mathrm{ab}$ & $12.98 \mathrm{ab}$ \\
\hline & 75 & $13.12 \mathrm{a}$ & $10.56 \mathrm{a}$ & $17.89 \mathrm{a}$ & $12.90 \mathrm{a}$ & $12.39 \mathrm{a}$ & $9.23 \mathrm{a}$ & $17.45 \mathrm{a}$ & $13.60 \mathrm{a}$ \\
\hline
\end{tabular}

Values followed by the same letter (s) within column are not significantly different $(\mathrm{P}<0.05)$ 
Table 5: Effect of amino acids and humic acid on the chemical composition of onions in 2018/2019 and 2019/2020 seasons.

\begin{tabular}{|c|c|c|c|c|c|c|c|c|c|}
\hline \multicolumn{6}{|c|}{ First season } & \multicolumn{4}{|c|}{ Second season } \\
\hline \multicolumn{2}{|c|}{ Treatments } & $\begin{array}{c}\text { Ascorbic acid } \\
\text { (mg./100 g. F.W.) }\end{array}$ & $\begin{array}{l}\text { Antioxidant } \\
\text { activity (\%) }\end{array}$ & $\begin{array}{c}\text { Crud protein } \\
(\%)\end{array}$ & $\begin{array}{c}\text { Total phenol } \\
\text { content } \\
\text { (mg./100 g.) }\end{array}$ & $\begin{array}{c}\text { Ascorbic acid } \\
\text { (mg/100 g. } \\
\text { F.W.) }\end{array}$ & $\begin{array}{l}\text { Antioxidant } \\
\text { activity (\%) }\end{array}$ & $\begin{array}{c}\text { Crud } \\
\text { protein }(\%)\end{array}$ & $\begin{array}{c}\text { Total phenol } \\
\text { content } \\
\text { (mg./100 g.) }\end{array}$ \\
\hline \multicolumn{10}{|c|}{ Amino levels $(\mathrm{cm} / \mathrm{L})$} \\
\hline \multicolumn{2}{|c|}{$\mathbf{0}$} & $3.90 \mathrm{C}$ & $61.60 \mathrm{C}$ & $13.00 \mathrm{C}$ & $5.90 \mathrm{C}$ & $4.02 \mathrm{C}$ & $65.4 \mathrm{C}$ & $12.16 \mathrm{C}$ & $6.90 \mathrm{C}$ \\
\hline \multicolumn{2}{|c|}{1} & $4.30 \mathrm{~B}$ & $65.90 \mathrm{~B}$ & $14.06 \mathrm{~B}$ & $6.20 \mathrm{~B}$ & $4.47 \mathrm{~B}$ & $70.1 \mathrm{~B}$ & $12.83 \mathrm{~B}$ & $7.30 \mathrm{~B}$ \\
\hline \multicolumn{2}{|c|}{2} & $4.70 \mathrm{~A}$ & $70.10 \mathrm{~A}$ & $15.50 \mathrm{~A}$ & $6.70 \mathrm{~A}$ & $5.10 \mathrm{~A}$ & $73.9 \mathrm{~A}$ & $13.69 \mathrm{~A}$ & $7.70 \mathrm{~A}$ \\
\hline \multicolumn{10}{|c|}{ Humic acid (kg/fed.) } \\
\hline \multicolumn{2}{|c|}{$\mathbf{0}$} & $4.40 \mathrm{D}$ & $67.50 \mathrm{D}$ & $13.00 \mathrm{D}$ & $6.40 \mathrm{D}$ & $4.76 \mathrm{D}$ & $70.00 \mathrm{D}$ & $13.17 \mathrm{D}$ & $7.30 \mathrm{D}$ \\
\hline \multicolumn{2}{|c|}{25} & $4.80 \mathrm{C}$ & $68.80 \mathrm{C}$ & $14.06 \mathrm{C}$ & $6.70 \mathrm{C}$ & $4.96 \mathrm{C}$ & $73.00 \mathrm{C}$ & $13.59 \mathrm{C}$ & $7.60 \mathrm{C}$ \\
\hline \multicolumn{2}{|c|}{50} & $5.00 \mathrm{~B}$ & $70.30 \mathrm{~B}$ & $15.93 \mathrm{~B}$ & $7.10 \mathrm{~B}$ & $5.23 \mathrm{~B}$ & $76.00 \mathrm{~B}$ & $14.34 \mathrm{~B}$ & $7.80 \mathrm{~B}$ \\
\hline \multicolumn{2}{|c|}{75} & $5.20 \mathrm{~A}$ & $73.00 \mathrm{~A}$ & $16.68 \mathrm{~A}$ & $7.80 \mathrm{~A}$ & $5.50 \mathrm{~A}$ & $77.90 \mathrm{~A}$ & $14.96 \mathrm{~A}$ & $8.00 \mathrm{~A}$ \\
\hline \multicolumn{10}{|c|}{ The interaction } \\
\hline \multirow{4}{*}{$\mathbf{0}$} & $\mathbf{0}$ & $3.70 \mathrm{~h}$ & $59.70 \mathrm{i}$ & $12.34 \mathrm{i}$ & $5.67 \mathrm{i}$ & $3.80 \mathrm{i}$ & $60.20 \mathrm{i}$ & $11.74 \mathrm{i}$ & $6.45 \mathrm{i}$ \\
\hline & 25 & $3.90 \mathrm{~h}$ & $60.10 \mathrm{~h}$ & $12.89 \mathrm{i}$ & $5.90 \mathrm{~h}$ & $3.90 \mathrm{i}$ & $64.30 \mathrm{~h}$ & $11.89 \mathrm{~h}$ & $6.89 \mathrm{~h}$ \\
\hline & 50 & $4.10 \mathrm{~g}$ & $61.20 \mathrm{gh}$ & $13.11 \mathrm{~h}$ & $6.11 \mathrm{~g}$ & $4.10 \mathrm{~h}$ & $67.50 \mathrm{~g}$ & $12.34 \mathrm{~g}$ & $7.12 \mathrm{~g}$ \\
\hline & 75 & $4.20 \mathrm{~g}$ & $65.40 \mathrm{~g}$ & $13.67 \mathrm{~g}$ & $6.23 \mathrm{f}$ & $4.30 \mathrm{~g}$ & $69.70 \mathrm{f}$ & $12.67 \mathrm{f}$ & $7.23 \mathrm{f}$ \\
\hline \multirow{4}{*}{1} & $\mathbf{0}$ & $4.40 \mathrm{f}$ & $67.40 \mathrm{f}$ & $14.67 \mathrm{fg}$ & $6.33 \mathrm{e}$ & $4.60 \mathrm{fg}$ & $70.10 \mathrm{e}$ & $12.89 \mathrm{ef}$ & $7.35 \mathrm{e}$ \\
\hline & 25 & $4.70 \mathrm{e}$ & $69.70 \mathrm{e}$ & $14.80 \mathrm{f}$ & $6.47 \mathrm{de}$ & $4.90 \mathrm{f}$ & $73.40 \mathrm{de}$ & $13.45 \mathrm{e}$ & $7.56 \mathrm{~d}$ \\
\hline & 50 & $4.90 \mathrm{~d}$ & $70.10 \mathrm{~d}$ & $15.78 \mathrm{e}$ & $6.78 \mathrm{~d}$ & $5.30 \mathrm{e}$ & $75.50 \mathrm{~d}$ & $13.78 \mathrm{de}$ & $7.90 \mathrm{~cd}$ \\
\hline & 75 & $5.10 \mathrm{~cd}$ & $73.30 \mathrm{c}$ & $16.78 \mathrm{~d}$ & $7.45 \mathrm{c}$ & $5.60 \mathrm{~d}$ & $76.80 \mathrm{c}$ & $14.67 \mathrm{~d}$ & $8.11 \mathrm{c}$ \\
\hline \multirow{4}{*}{2} & $\mathbf{0}$ & $5.30 \mathrm{c}$ & $75.60 \mathrm{~b}$ & $17.89 \mathrm{~cd}$ & $7.49 \mathrm{bc}$ & $5.90 \mathrm{~cd}$ & $79.70 \mathrm{bc}$ & $14.89 \mathrm{~cd}$ & $8.23 \mathrm{bc}$ \\
\hline & 25 & $5.90 \mathrm{~b}$ & $76.80 \mathrm{~b}$ & $17.90 \mathrm{c}$ & $7.90 \mathrm{~b}$ & $6.10 \mathrm{c}$ & $82.30 \mathrm{~b}$ & $15.45 \mathrm{c}$ & $8.56 \mathrm{~b}$ \\
\hline & 50 & $6.20 \mathrm{ab}$ & $79.70 \mathrm{ab}$ & $18.90 \mathrm{~b}$ & $8.45 \mathrm{ab}$ & $6.30 \mathrm{~b}$ & $85.10 \mathrm{ab}$ & $16.90 \mathrm{~b}$ & $8.67 \mathrm{ab}$ \\
\hline & 75 & $6.40 \mathrm{a}$ & $80.30 \mathrm{a}$ & $19.60 \mathrm{a}$ & $8.78 \mathrm{a}$ & $6.60 \mathrm{a}$ & $87.40 \mathrm{a}$ & $17.56 \mathrm{a}$ & $8.90 \mathrm{a}$ \\
\hline
\end{tabular}

Values followed by the same letter (s) within column are not significantly different $(\mathrm{P}<0.05)$ 


\section{References}

A.O.A.C., 1990. Association of official analytical chemists. Official Methods of Analysis.15th ed., Washington, D.C. USA.

Abd El-Rheem, K.M., S.M. El-Sawy, Heba S. El-Batran and Y.A. El-Damarawy, 2020. Effect of spraying K-humate and amino acids on growth, yield and nutrient balance of potato plants. Med. J. Soil Sci., 1 (1): 18-27.

Abdelhamid, M.T., E.M. Selim and A.M. EL-Ghamry, 2011. Integrated Effects of Bio and Mineral Fertilizers and Humic Substances on Growth, Yield and Nutrient Contents of Fertigated Cowpea (Vigna unguiculata L.) Grown on Sandy Soils. Journal of Agronomy, 10(1): 34-39. DOI: $10.3923 /$ ja.2011.34.39.3.

Abdel-Mawgoud, A.M.R., A. M. El-Bassiouny, A. Ghoname, and S.D. Abou-Hussein, 2011. Foliar Application of Amino Acids and Micronutrients Enhance Performance of Green Bean Crop under Newly Reclaimed Land Conditions, Australian Journal of B asic and Applied Sciences, 5 (6): $51-55$.

Akinremi, O.O., H.H. Janzen, R.L. Lemke and F.J. Larney, 2000. Response of canola, wheat and green beans to leonardite additions. Canadian J. of Soil Sci., 80: 437-443.

Akthar, T., S.M. Ismail and F.S. Al-Nakhlawy, 2017. Optimization of Humic acid application rate by evaluating the response of mung bean (Vigna radiata) yield, growth components and soil properties in western region of Saudi Arabia. Int. J. Biosci., 1(1): 240-248.

Atiyeh, R.M., S. Lee, C.A. Edwards, N.Q. Arancon and J.D. Metzger, 2002. The influence of humic acids derived from earthworm processed organic wastes on plant growth. Bioresource Technol., 84(1): 7-14.

Bama, K.S. and G. Selvakumari, 2001. Effect of humic acid on growth yield and nutrition of amaranthus. South Indian Hort., 49: 155-159.

Calvo P., L. Nelson and J.W. Kloepper, 2014. Agricultural uses of plant biostimulants. Plant and Soil, 383: 3-41.

Canellas, L.P. and F.L. Olivares, 2014. Physiological responses to humic substances as plant growth promoter. Chemical and Biological Technologies in Agriculture, 1(3): 1-11. https: //doi. Org /10.1186/2196-5641 -1 -3.

Canellas, L.P., L.R.L. Teixeira Junior, L.B. Dobbss, C.A. Silva, L.O. Medici, D.B. Zandonadi, and A.R. Façanha, 2008. Humic acids cross interactions with root and organic acids. Annals of Applied Biology, 153(2): 157-166. http://dx.doi.org/10.1111/j.1744-7348.2008.00249.x

CAH (Central Administration of Horticulture), 2019. Ministry of Agriculture and Land Reclamation, Cairo, Egypt.

Chen, Y. and T. Aviad, 1990. Effects of humic substances on plant growth. In: Mac Carthy, P., Clapp, C.E., Malcolm, R.L., Bloom, P.R. (Eds.), Humic Substances in Soil and Crop Sciences: Selected Readings. ASA and SSSA, Madison, WI, 161- 186.

Cottenie, A., M. Nerloo, G. Velghe, and L. Kiekens, 1982. Biological and analytical aspects of soil pollution. Lab. Of Analytical Agro. State Univ. of Calif. Division of Agric. Sci., 60-69.

Davies P.J., 2010. The plant hormones: Their nature, occurrence, and functions. In: Davies P.J. (ed.): Plant Hormones: Biosyn-thesis, Signal Transduction and Action. 3 rd Edition. Dordrecht, Springer Science Business Media B.V., 1 -15.

Doklega, Samar M.A., 2017. Effect of farmyard manure, sulphur and humic acid fertilization on Onion productivity. International Journal of Advanced Research in Biological Sciences, 4(7): 38-52. DOI: http://dx.doi.org/10.22192/ijarbs.201 7.04.07.005.

El-Bassiony, A.M., S.H. Mahmoud, S.M. El-Sawy and Shaymaa I Shedeed, 2020. Stimulation of Growth and Productivity of Onion Plants by Selenium and Growth Active Substances. Middle East Journal of Agriculture Research, 9(3): 637-645. DOI: 10.36632/mejar/2020.9.3.50.

El-Desouky, S.A., F.H. Ismaeil, A.L. Wanas, E.S.L. Fathy and M.M. Abd El-All, 2011. Effect of yeast extract, amino acids and citric acid on physioanatomical aspects and productivity of tomato plants grown in late summer season. Minufiya J. Agric. Res., 36(4): 859-884.

El-Zohiri, S.S.M. and Y.M. Asfour, 2009. Effect of some organic compounds on growth and productivity of some potato cultivars. Annals of Agric. Sci., Moshtohor, 47 (3): 403 -415. 
Geries, L.S.M., 2013. Effect of nitrogen fertilizer and foliar spraying with humic acid on growth and yield of onion (Allium cepa L.). Egypt. J. of Appl. Sci., 28 (4): 204-226.

Hartz, T.K. and T.G. Bottoms. 2010. Humic substances generally ineffective in improving vegetable crop nutrient uptake or productivity. HortScience, 45(6): 906-910.

Jaggi, R.C. 2005. Sulphur as production and protection agent in onion (Allium cepa). Indian J. Agric. Sci., 75(12): 805-808.

Kandil, A.A., A.E. Sharief, F.H. Fathalla, 2013. Onion yield as affected by foliar application with amino and humic acids under nitrogen fertilizer levels. ESci J. Crop Prod., 2 (02): 62-72.

Korkmaz, A.R., D.S. Ferit Kocac, S.A. Ozlem De gera and A.R. Demirkırıand, 2012. Alleviation of salt-induced adverse effects in pepper seedlings by seed application of glycinebetaine. J. Sci. Hort., 148: 197-205.

Liu X.Q., K.Y. Ko, S.H. Kim and K.S. Lee, 2008. Effect of amino acid fertilization on nitrate assimilation of leafy radish and soil chemical properties in high nitrate soil. Communications in Soil Science and Plant Analysis, 39: 269-281.

Luciano, P.C. , L.O. Fábio, O.A. Natália, L.J. Davey, N. Antonio, M. Pierluigi and P. Alessandro, 2015. Review: Humic and fulvic acids as biostimulants in horticulture. Scientia Horticulturae, 196 : $15-27$.

Marschener, P., 2012. Marschener's Mineral nutration of higher plants. Third Edition. Academic Press in an imprint of Elsevier.

MSTAT Development Team, 1989. MSTAT user's guide: A microcomputer program for the design, management and analysis of agronomic research experiments. Michigan State University East Lansing, U.S.A.

Olk, D.C., L.D. Dana, J.R. Scoresby, R.C. Chad and W.D. Jerald, 2019. Can humic products substantially improve ecosystem quality and economic yield? Silva Balcanica, 20 (1) : 95-110.

Pettit, R.E., 2004. Organic Matter, Humus, Humate, Humic Acid, Fulvic Acid and Humin: Their Importance in Soil Fertility and Plant Health, CTI Research 1-17.

Pratelli, R. and G. Pilot. 2007. Altred amino acid metabolism in glutamine dumperI plants. Plant signal Behav., 2(3): 182-184.

Radwan, E.A. and Z.S.A. El- Shall, 2011. Effect of potassium fertilization and humic acid application on plant growth and productivity of potato plants under clay soil. J. Plant Production, Mansoura Univ., 2 (7): 877 - 890.

Rai, V.K., 2002. Role of amino acids in plant responses to stress. Biol. Plant., 45: 471-478. Doi: http://dx.doi.org/10.1023/A:1022308229759.

Rizk, F.A., A.M. Shaheen, S.M. Singer and Ommima A. Sawan. 2013. The productivity of potato plants affected by urea fertilizer as foliar spraying and humic acid added with irrigation water. Middle East Journal of Agriculture Research, 2 (2): 76-83.

Sajid, M., R. Abdur, T.S. Syed, J. Ibadullah, H. Ihsanul, H. Bibi, Z. Muhammad, A. Riaz and Z. Hayat, 2012. Humic acids affect the bulb production of onion cultivars. African Journal of Microbiology Research, 6(28): 5769-5776. OI: 10.5897/AJMR11.1643.

Sarhan, T.Z., 2011. Effect of humic acid and seaweed extracts on growth and yield of potato plant (Solanum tubersum L) desiree CV. Mesopotamia J. of Agric., 39(2) : 19-27.

Serna, M.Y., F.H. Ndez, F.A. Coll, Y.T. Coll, and A.D. Amoro, 2012. Brassinosteroid analogues effects on the yield and quality parameters of greenhouse-grown pepper (Capsicum annuum L.). J. Plant Growth Regul., 68: 333-342.

Shafeek, M.R., Y.I. Helmy and M.M.B. Shokr, 2014. Response of hot pepper (Capsicum annum L.) to nitrogen fertilizer and humic acid levels under sandy soil conditions in plastic house. Middle East Journal of Agriculture Research, 3(2): 235-241.

Shaheen, A.M., Fatma, A. Rizk, Omaima, M. Sawan and M.O. Bakry, 2013. Sustaining the Quality and Quantity of Onion Productivity Throughout Complementrity Treatments Between Compost Tea and Amino Acids. Middle East Journal of Agriculture Research, 2(4): 108-115.

Shehata, S.A. and A. Abdel-Wahab, 2018. Influence of compost, humic acid and amino acids on sweet pepper growth, productivity and storage-ability. Middle East Journal of Applied Sciences, 8(3): 922-927.

Snedecor G.W., and W.G. Cochran, 1982. Statistical methods. 7th ed. Iowa State Univ. Press, Iowa Steel, R.G.D. and J.H. Torrie, 1980. Principles and Procedures of Statistics. McGraw Hill, New York. 
Tugnoli, V. and G. Bettini, 2003. The use of foliar fertilizer application in sugar beet growing. 1st Joint IIRBASSBT Congress, 26th Feb -1st March 2003, San Antonio (USA), 655-660.

Zhang, X., 1997. Influence of plant growth regulators on turfgrasss growth antioxidant status and drought tolerance. Ph.D Thesis, Faculty Virginia Polytechni (Institute and State University). 